\title{
PROFIL LEMAK DARAH ITIK LOKAL JANTAN YANG DIBERI CAMPURAN BAHAN PAKAN LOKAL YANG DIFERMENTASI DENGAN EFFECTIVE MICROORGANISM-4
}

\author{
The Blood Lipid Profile of Male Local Duck Fed with Mixed Local Feeds Fermented by \\ Effective Microorganism-4
}

\author{
Dian Septinova*, Farida Fathul, Purnama Edy Santosa, Madi Hartono \\ Department of Animal Husbandry, Faculty of Agriculture, University of Lampung \\ Jl. Soemantri Brojonegoro No. 1, Gedong Meneng, Rajabasa, Bandar Lampung 35145 \\ *E-mail: dian.septinova@fp.unila.ac.id
}

Submitted : April 8, 2020

Accepted : November 29, 2020

\begin{abstract}
ABSTRAK
Daging itik mengandung cukup banyak kolesterol. Bungkil kelapa sawit, onggok dan dedak merupakan bahan pakan lokal yang banyak digunakan oleh peternak itik tradisional. Pengolahan pakan dengan cara fermentasi diharapkan dapat mengurangi kadar kolesterol itik. Tujuan dari penelitian ini adalah untuk mengetahui pengaruh penggantian ransum komersil dengan campuran bungkil kelapa sawit, onggok, dan dedak yang difermentasi dengan EM-4 terhadap profil lemak darah itik lokal jantan. Penelitian ini menggunakan metode eksperimen Rancangan Acak Lengkap dengan lima perlakuan dan empat ulangan. Setiap ulangan terdiri dari dua ekor itik. Perlakuannya adalah ransum komersil 100\% (P0), ransum komersil $95 \%$ + campuran bahan pakan fermentasi 5\% (P1), ransum komersil $90 \%$ + campuran bahan pakan fermentasi 10\% (P2), ransum komersil $85 \%$ + campuran bahan pakan fermentasi $15 \%$ (P3), dan ransum komersil 80\% + campuran bahan pakan fermentasi 20\% (P4). Data dianalisis dengan menggunakan analisis ragam (One Way Anova) dan apabila berpengaruh nyata dilanjutkan dengan Uji Beda Nyata Terkecil (BNT). Hasil analisis ragam menunjukkan bahwa penambahan campuran bungkil kelapa sawit, onggok, dan dedak terfermentasi sampai dengan level $20 \%$ dalam ransum komersil tidak berpengaruh nyata $(\mathrm{P}>0.05)$ terhadap kadar kolesterol, HDL, LDL dan trigliserida darah itik Mojosari jantan. Kesimpulan penelitian ini bahwa pemberian campuran bahan pakan fermentasi dapat digunakan sampai dengan $20 \%$ dalam ransum tanpa memberikan efek negatif terhadap lemak darah itik.
\end{abstract}

Kata Kunci: EM-4, HDL, Kolesterol, LDL, Trigliserida.

\section{ABSTRACT}

Duck meat contains quite a lot of cholesterol. Oil palm cake, onggok, and bran are local feed ingredients that are widely used by traditional duck breeders. Fermented feed processing is expected to reduce levels of duck cholesterol. The purpose of this study was to determine the effect of replacing commercial rations with a mixed oil palm cake, onggok and bran fermented with EM-4 on the blood lipid profile of male local ducks. This study used a Completely Randomized Design with five treatments and four replacements. The treatment was commercial ration 100\% (P0); $95 \%$ commercial ration + mixture of $5 \%$ fermented feed ingredients $(P 1), 90 \%$ commercial ration $+10 \%$ fermented feed ingredients mixture $(P 2), 85 \%$ commercial ration + a mixture of $15 \%$ fermented feed ingredients $(P 3)$, and $80 \%$ commercial ration $+20 \%$ fermented feed ingredients $(P 4)$. Data were analyzed using analysis of variance (One Way ANOVA) and if it had significantly affected, the analysis was continued with LSD. The results of variance analysis showed that the addition of mixed palm oil cake, onggok, and fermented bran up to a level of $20 \%$ in commercial rations had no significant effect $(P>0.05)$ on blood cholesterol, HDL, LDL and triglycerides of male local ducks. Conclusion of this research was giving a mixture of fermented feed ingredients can be used up to $20 \%$ in the ration without giving a negative effect to duck blood lipid.

Keywords: Cholesterol, EM-4, HDL, LDL, Triglycerides 


\section{PENDAHULUAN}

Daging itik relatif banyak disukai oleh masyarakat. Pasokan daging itik pedaging yang terbatas membuka peluang bagi peternak untuk memelihara itik jantan dari tipe petelur untuk dimanfaatkan sebagai penghasil daging. Daging itik mengandung lebih kurang 5,71\% lemak dan $0,06 \%$ kolesterol (Pagala dan Agustina 2009). Kandungan lemak daging itik $(8,2 \%)$ lebih tinggi dibandingkan dengan daging ayam (4,8\%) (Yulianti et al. 2013). Saat ini masyarakat cenderung menyukai daging itik yang rendah lemak, maka perlu adanya upaya untuk menurunkan kandungan lemak pada daging itik.

Bungkil kelapa sawit, onggok, dan dedak merupakan limbah agroindustri yang banyak digunakan oleh peternak tradisional sebagai bahan pakan dalam ransum itik. Namun, kandungan serat kasar yang tinggi dan adanya zat antinutrisi pada bahan limbah agroindustri tersebut menyebabkan nilai guna dari bahan tersebut menjadi rendah karena kemampuan itik untuk mencerna dan menyerap zat-zat gizi yang ada dalam bahan tersebut rendah. Fermentasi campuran bungkil kelapa sawit, onggok, dan dedak (80:10:10) dengan EM-4 nyata $(\mathrm{P}<0,05)$ dapat meningkatkan nilai nutrisi campuran bahan pakan tersebut (Septinova et al. 2017).

Probiotik EM-4 adalah suatu campuran mikroorganisme yang bermanfaat terutama mengandung bakteri fotosintetik, asam laktat, Actinomycetes, jamur, kapang dan ragi (Telew et al., 2013). Fermentasi palm fronds dengan EM-4 dapat menurunkan kandungan serat kasar, meningkatkan kandungan protein kasar, dan meningkatkan kecernaan (Rostini 2017).

Pemberian pakan fermentasi nyata dapat meningkatkan pertumbuhan dan kualitas karkas, serta menurunkan kolesterol serum itik (Bidura et al. 2008). Menurut Yulianti et al. (2013), terdapat kaitan antara kadar kolesterol darah dengan kolesterol daging. Rendahnya kadar kolesterol darah akan berdampak terhadap rendahnya kolesterol daging.

Penurunan kadar kolesterol darah akan berdampak terhadap rendahnya kolesterol daging dan hingga saat ini belum diketahui pengaruh pemberian campuran bungkil kelapa sawit, onggok, dan dedak terfermentasi terhadap profil lemak darah itik lokal jantan, oleh karena itu penelitian ini dilakukan.

\section{MATERI DAN METODE}

\section{Materi}

Materi yang digunakan adalah itik Mojosari jantan berumur 3 minggu sejumlah 40 ekor. dengan bobot badan 458,53 $\pm 38,08 \mathrm{~g}$ yang berasal dari Peternakan Eko Jaya di Pringsewu. Itik dipelihara pada petak kandang ukuran ( $\mathrm{p}$ x 1 x t) $80 \times 60 \times 60 \mathrm{~cm}$. Setiap petak berisi dua ekor itik dan sebuah tempat makan dan minum. Itik diberi makan sehari dua kali dan air minum disediakan secara ad libitum. Itik dipelihara selama 4 minggu.

Ransum yang digunakan yaitu ransum komersil untuk broiler dan campuran ransum fermentasi (Tabel 1). Ransum dan air minum diberikan secara adlibitum.

\section{Metode \\ Rancangan Penelitian}

Penelitian ini menggunakan Rancangan Acak Lengkap (RAL) dengan lima perlakuan dan empat ulangan untuk setiap perlakuan. Perlakuan yang diberikan adalah ransum komersil 100\% (P0); ransum komersil 95\% + campuran bahan pakan fermentasi 5\% (P1); ransum komersil 90\% + campuran bahan pakan fermentasi 10\% (P2); ransum komersil $85 \%$ + campuran bahan pakan fermentasi 15\% (P3); dan ransum komersil 80\% + campuran bahan pakan fermentasi $20 \%$ (P4) (Tabel 2). Pada saat itik berumur 7 minggu dilakukan pengambilan darah melalui vena brachialis untuk diamati kadar kolesterol, HDL, LDL, dan trigliserida.

Tabel 1. Kandungan nutrisi campuran bahan pakan hasil fermentasi (The nutritional content of the fermented feed ingredients mixture)

\begin{tabular}{lc}
\hline Kandungan Nutrisi (Nutrition content) & Jumlah (Amount) \\
\hline Air (water) (\%)* & 14,50 \\
Protein kasar (Crude protein) (\%)* & 14,91 \\
Lemak kasar (Crude fat) (\%)* & 2,93 \\
Serat kasar (Crude fiber) (\%)** & 18,49 \\
Abu (Ash) (\%)** & 5,86 \\
Energi metabolis (metabolic energy) (kkal/kg)*** & 2402,89 \\
\hline
\end{tabular}

Keterangan: *) hasil analisis laborotarium Nutrisi Ternak Unila, **) hasil analisis laboratorium THP Politani, ***) hasil perhitungan menurut rumus Clegg dan Carpenter (Anggorodi, 1994). 


\section{Fermentasi Pakan}

Bungkil kelapa sawit, onggok, dan dedak ditimbang dengan perbandingan 80:10:10. Selanjutnya mencampur dengan air panas sampai kadar bahan $70 \%$. Setelah dingin, disemprot dengan campuran EM-4 sebanyak 3\% (v/b) dan molases 3\% (v/b) kemudian diaduk secara merata. Selanjutnya adonan dimasukkan ke dalam plastik, dipadatkan dan diikat serta didiamkan selama 3 hari, setelah itu produk fermentasi dibuka dan dijemur.

\section{Pengambilan Sampel Uji Darah}

Pengambilan darah dilakukan saat itik memasuki umur 7 minggu. Darah diambil sebanyak $3 \mathrm{ml}$ pada bagian vena brachialis, kemudian darah dengan segera dimasukkan pada vacutainer yang sudah diisi dengan anti koagulan EDTA. Darah kemudian disentrifius untuk memisahkan plasma darah, plasma kemudian dimasukaup sample dan disimpan dalam freezer dengan suhu $-20{ }^{\circ} \mathrm{C}$. Prosedur analisis kolesterol menggunakan metode enzymatic chalorymetric test (CHOD-POD) dengan reagen kit produksi Cypress Diagnostics.

\section{Analisis Data}

Data yang diperoleh dianalisis dengan menggunakan analisis sidik ragam (One Way Anova) dan apabila berpengaruh nyata dilanjutkan dengan Uji Beda Nyata Terkecil.

\section{HASIL DAN PEMBAHASAN}

\section{Kadar Kolesterol Darah}

Hasil analisis ragam menunjukkan bahwa level pemberian campuran bahan pakan fermentasi di dalam ransum komersil tidak berpengaruh nyata $(\mathrm{P}>0,05)$ terhadap kadar kolesterol darah itik Mojosari jantan umur 7 minggu. Hasil penelitian ini berbeda dengan penelitian Trisnadewi et al. (2015) bahwa pemberian pakan tahu terfermentasi sampai dengan $30 \%$ dalam ransum nyata dapat menurunkan kadar kolesterol serum itik. Per kadar kolesterol darah itik yang tidak berbeda nyata antar perlakuan disebabkan oleh kandungan nutrisi antar perlakuan yang relatif tidak jauh berbeda sehingga laju digesti makanan dalam saluran pencernaan maupun kecepatan sintesis kolesterol di dalam tubuh pun tidak berbeda. Menurut Wijaya et al. (2013), faktor ransum yang sama membuat kemampuan setiap genetik itik dalam mengabsorbsi lemak relatif sama sehingga kadar kolesterol darahnya pun relatif sama.

Pada penelitian ini, pemberian probiotik EM-4 dalam fermentasi pakan campuran bungkil kelapa sawit, onggok dan dedak belum cukup mampu untuk mengikat kolesterol darah sehingga kolesterol darah pada itik yang diberi pakan terfermentasi tidak berbeda dengan itik yang diberi ransum kontrol. Penyebabnya adalah viabilitas probiotik EM-4 dalam campuran pakan yang sudah menurun selama penjemuran dan penyimpanan.

Tabel 2. Kandungan nutrisi ransum perlakuan (Nutritional content of treatment rations)

\begin{tabular}{lrrrrr}
\hline Kandungan Nutrisi & \multicolumn{1}{c}{ P0 } & P1 & P2 & P3 & P4 \\
\hline Air/water $(\%)^{*}$ & 12,00 & 12,12 & 12,25 & 12,37 & 12,50 \\
Protein kasar/Crude protein (\%)* & 22,50 & 21,64 & 21,29 & 20,94 & 20,58 \\
Lemak kasar/Crude fat (\%)* & 5,00 & 4,90 & 4,79 & 4,69 & 4,59 \\
Serat kasar/Crude fiber(\%)** & 5,00 & 5,67 & 6,35 & 7,02 & 7,70 \\
Abu/Ash (\%)** & 7,00 & 6,94 & 6,89 & 6,83 & 6,77 \\
Energi metabolis/ metabolic energy & & & & & \\
(kkal/kg)*** & 48,50 & 48,73 & 48,43 & 48,09 & 47,86 \\
Air/water $(\%)^{*}$ & 3092 & 3058 & 3023 & 2989 & 2952.00 \\
\hline
\end{tabular}

Keterangan: *) hasil analisis laborotarium Nutrisi Ternak Unila, **) hasil analisis laboratorium THP Politani, ***) hasil perhitungan menurut rumus Clegg dan Carpenter (Anggorodi, 1994).

Tabel 3. Profil lemak darah itik Mojosari jantan (Blood fat profile of male Mojosari ducks)

\begin{tabular}{lrrrrr}
\multicolumn{1}{c}{ Peubah } & P0 & \multicolumn{1}{c}{ P1 } & \multicolumn{1}{c}{ P2 } & \multicolumn{1}{c}{ P3 } & \multicolumn{1}{c}{ P4 } \\
\hline Kolesterol total (mg/dl) & 171,88 & 162,92 & 181,65 & 161,37 & 193,23 \\
HDL (mg/dl) & 90,69 & 82,16 & 92,62 & 78,54 & 107,22 \\
LDL (mg/dl) & 131,29 & 122,54 & 137,14 & 119,96 & 150,23 \\
Trigliserida (mg/dl) & 63,24 & 71,61 & 72,17 & 90,78 & 48,45 \\
\hline
\end{tabular}


Kadar kolesterol darah itik jantan yang tidak berbeda antara P0, P1, P2, P3, dan P4 juga disebabkan oleh kemampuan tubuh itik untuk melaksanakan biosintesis de novo sehingga kadar kolesterol darah tetap berada dalam kisaran normal. Biositesis de novo merupakan suatu upaya untuk mempertahankan homeostatis kolesterol di dalam darah dan bergantung pada lipoprotein (Trapani, 2012). Menurut Wijaya (2013), kolesterol dalam plasma darah $80 \%$ berasal dari biosintesis de novo sisanya $20 \%$ berasal dari makanan yang dikonsumsi. Muliani (2014) menyatakan bahwa ketika asupan kolesterol dari makanan rendah, biosintesis de novo memproduksi kolesterol untuk mendukung berbagai proses biologis dalam tubuh yang membutuhkan kolesterol. Proses ini yang menyebabkan kadar kolesterol di dalam darah tetap terlihat stabil.

Rata-rata kadar kolesterol darah itik lokal jantan pada penelitian ini berkisar antara 161,37 (P3) sampai 193,23 (P4) mg/dl. Menurut Thrall et al. (2012), spesies burung termasuk itik memiliki kolesterol darah berkisar antara 100-250 $\mathrm{mg} / \mathrm{dl}$. Itu berarti kolesterol darah itik pada penelitian itik tergolong normal, sehingga campuran bahan pakan lokal terfementasi ini dapat diberikan untuk menggantikan ransum komersil sampai dengan tingkat 20\%. Hal ini didukung oleh Septinova et al. (2019 bahwa pemberian produk fermentasi campuran bungkil kelapa sawit, onggok, dan dedak dapat digunakan sampai dengan 20\% dalam ransum itik lokal jantan karena tidk berpengaruh negatif terhadap bobot tubuh, konsumsi ransum, dan konversi ransum.

\section{Kadar High Density Lipoprotein darah}

Hasil analisis ragam menunjukkan bahwa pemberian campuran bungkil kelapa sawit, onggok, dan dedak terfermentasi EM-4 sampai dengan tingkat 20\% dalam ransum komersil berpengaruh tidak nyata $(\mathrm{P}>0,05)$ terhadap kadar HDL darah itik Mojosari jantan. Hal tersebut disebabkan karena kandungan kolesterol darah itik Mojosari jantan tidak berbeda nyata. Hasanuddin et al. (2014) menyatakan bahwa High Density Lipoprotein (HDL) memiliki korelasi yang positif dengan LDL dan keduanya sangat dipengaruhi oleh kadar kolesterol dalam darah. Kolesterol ataupun prekusor pembentuk kolesterol yang telah dibongkar dari berbagai jaringan di tubuh akan dibawa oleh HDL menuju hati untuk kemudian dikeluarkan melalui ekskreta.

Kandungan serat kasar ransum perlakuan yang relatif sama pada $\mathrm{P} 0, \mathrm{P} 1, \mathrm{P} 2, \mathrm{P} 3$, dan $\mathrm{P} 4$ dapat menjadi penyebab tidak berbedanya kadar HDL darah itik Mojosari jantan. Kadar HDL dipengaruhi oleh lingkungan dan genetik. Faktor lingkungan yang mempengaruhi HDL antara lain pakan yang diberikan (Hartini dan Okid 2009). Serat bersifat bulkiness yang dapat mempercepat transit pakan di dalam usus sehingga terjadi penurunan hidrolisis karbohidrat dan penyerapan hasil produknya. Penurunan absorpsi lemak, kolesterol, dan karbohidrat menyebabkan penurunan kadar insulin serum sehingga menurunkan ransangan sintesis kolesterol dan lipropotein (Lee et al., 2005).

Menurut Mustikaningsih (2010), kadar HDL yang baik adalah lebih dari $60 \mathrm{mg} / \mathrm{dl}$. Menurut Basmacioglu dan Ergul (2005), kisaran HDL normal yaitu $>22 \mathrm{mg} / \mathrm{dl}$. Pada penelitian ini, kadar HDL darah itik baik pada yang mendapat ransum kontrol (P0) maupun yang mendapat pakan fermentasi semuanya adalah normal, yaitu berkisar 78,54 (P3) -107,22 (P4) mg/dl.

\section{Kadar Low Density Lipoprotein Darah}

Hasil analisis ragam menunjukkan bahwa pemberian campuran bungkil kelapa sawit, onggok, dan dedak terfermentasi EM-4 sampai dengan level $20 \%$ dalam ransum komersil tidak berpengaruh nyata $(\mathrm{P}>0,05)$ terhadap kadar LDL darah itik Mojosari jantan umur 7 minggu. Hal ini disebabkan probiotik EM-4 yang ditambahkan sudah dalam kondisi inaktif selama proses penjemuran dan penyimpanan ransum. Probiotik tersebut aktif saat proses fermentasi untuk meningkatkan kualitas campuran pakan lokal.

Kadar LDL yang tidak berbeda juga disebabkan oleh kadar kolesterol darah itik yang juga tidak berbeda nyata antar P0, P1, P2, P3, dan P4. Lipoprotein LDL berfungsi merupakan lipoprotein yanguntuk menjadi karier utama mengangkut kolesterol dari hati ke jaringan tubuh termasuk ke darah. (Montgomery et al., .1993). Semakin tinggi kadar kolesterol total maka akan berkorelasi positif dengan peningkatan kadar LDL plasma itik (Arini 2016).Perlakuan level pemberian campuran bungkil kelapa sawit, onggok, dan dedak yang difermentasi dengan EM-4 memberikan pengaruh yang tidak nyata terhadap LDL karena kandungan nutrisi ransum dan konsumsi ransum yang tidak jauh berbeda antara P0, P1, P2, P3, dan P4. Kadar LDL darah normal menurut Basmacioglu dan Ergul (2005) adalah $<130 \mathrm{mg} / \mathrm{dl}$. Kadar LDL darah itik jantan lokal pada penelitian ini adalah 119,96 -150,23 $\mathrm{mg} / \mathrm{dl}$. 


\section{Kadar Trigliserida Darah}

Trigliserida merupakan prekursor pembentukan energi. Apabila sel membutuhkan energi, enzim lipase dalam sel lemak akan memecah trigliserida menjadi gliserol dan asam lemak serta melepasnya ke dalam pembuluh darah. Hasil analisis ragam menunjukkan level pemberian campuran bungkil kelapa sawit, onggok, dan dedak terfermentasi berpengaruh tidak nyata $(\mathrm{P}>0,05)$ terhadap kadar trigliserida darah itik Mojosari jantan umur 7 minggu. Hal tersebut dapat disebabkan karena kandungan nutrisi ransum perlakuan terutama BETN dan konsumsi ransum itik pada $\mathrm{P} 0, \mathrm{P} 1, \mathrm{P} 2, \mathrm{P} 3$, dan $\mathrm{P} 4$ tidak jauh berbeda pada masing-masing perlakuan sehingga perlu upaya untuk peningkatan level pemberian campuran bahan pakan lokal.

Nutrisi ransum yang mempengaruhi kadar trigliserida darah adalah karbohidrat (BETN). Menurut Tim Laboratorium Ilmu dan Teknologi Pakan fakultas Peternakan IPB (2020), BETN merupakan tolak ukur secara kasar kandungan karbohidrat pada suatu pakan atau ransum. Kadar BETN ransum pada $\mathrm{P} 0, \mathrm{P} 1, \mathrm{P} 2, \mathrm{P} 3$, dan $\mathrm{P} 4$ relatif sama sehingga kadar trigliserida darah pada itik yang mendapat perlakuan P0, P1, P2, dan P3 pun berbeda tidak nyata.

\section{SIMPULAN}

Campuran bungkil kelapa sawit, onggok, dedak yang difermentasi dengan EM-4 dapat digunakan sampai dengan $20 \%$ dalam ransum komersil tanpa memberikan pengaruh penurunan terhadap profil lemah darah itik lokal jantan. Pemberian campuran bungkil kelapa sawit, onggok, dan dedak terfermentasi EM-4 sampai dengan 20\% ransum tidak berdampak terhadap penurunan kadar kolesterol, LDL, dan triglesrida serta peningkatan HDL darah itik lokal jantan.

\section{UCAPAN TERIMA KASIH}

Penulis mengucapkan terimakasih kepada Direktorat Riset dan Pengabdian Masyarakat, Direktorat Jenderal Penguatan Riset dan Pengembangan, Kementerian Riset, Teknologi, dan Pendidikan Tinggi dengan kontrak penelitian Nomor 583/UN26/21/KU2017 yang telah membiayai penelitian ini.

\section{DAFTAR PUSTAKA}

Anggorodi, R. 1994. Ilmu makanan ternak umum. PT. Gramedia Pustaka Utama. Jakarta

Arini, N.M.J. 2016. Evaluasi penggunaan tepung daun Indigofera zollingeriana dan Minyak
Lemuru dalam ransum terhadap metabolisme lipida itik. Tesis. Institut Pertanian Bogor. Bogor

BiduraI, G.N.G., I.K. Sukada, D.A. Warmadewi. 2008. Pengaruh penggunaan pollard, kulit kacang kedelai, dan pod kakao terfermentasi dengan ragi tape terhadap karkas, dan kadar kolesterol daging itik bali jantan. Majalah Ilmiah Peternakan, 10(2): $53-59$

Citrawidi, T. A., W. Murningsih, V.Y.D.B. Ismadi. 2012. Pengaruh pemeraman ransum dengan sari daun pepaya terhadap kolesterol darah dan lemak total ayam broiler. Anim. Agric. J., 1(1): 529 - 540.

Hasanuddin, S, V.D. Yunianto, Tristiarti. 2013. Profil lemak darah pada ayam broiler yang diberi pakan step down protein dengan penambahan air perasan jeruk nipis sebagai acidifier. J. Ilmu dan Teknologi Peternakan, 3(1): $11-17$.

Hartini, M., P. A. Okid. 2009. Kadar kolesterol darah tikus putih (Rattus norvegicus) hiperkolesterolemik setelah perlakuan VCO. Bioteknologi, 6(2): $55-62$.

Lee, S.O., A.L. Simons, P.A. Murphy, S. Hendrich. 2005. Soyasaponins lowered plasma cholesterol and increased fecal bile acids in female Golden Syrian hamsters. Experimental Biol. Med., 230(7): 472-478.

Muliani, H. 2014. Kadar kolesterol daging berbagai jenis itik (Anas domesticus) di Kabupaten Semarang. Buletin Anatomi dan Fisiologi 22(2): 75 - 82.

Montgomery, R., R. L. Dryer, T.W. Conway, A. A. Spector. 1993. Biochemistry: A Case Oriented Approach. Gadjah Mada University Press. Yogyakarta

Pagala, M. A., dan D. Agustina. 2009. Kualitas kolesterol itik Tegal dengan pemberian seledri (Apium graviolens) dan dedak padi. WARTA-WIPTEK 17: 97 - 100.

Rostini, T. 2017. Inoculan differences in the quality of physical and nutritionquality palm fermentation fronds as animal feed. J. of Agric. Vet. Sci., 10(1): 29 - 32

Septinova, D., F. Fathul, P.E. Santosa. 2017. Optimalisasi Fermentasi Campuran Bahan Pakan Alternatif untuk Mendukung Usaha Ternak Itik Jantan Lokal Berdaya Saing. Laporan Penelitian Produk Terapan. Universitas Lampung. Bandar Lampung.

Telew C, V.G. Kereh, I.M. Untu, B.W. Rembet. 2013. Pengayaan nilai nutriti sekam padi berbasis bioteknologi Effective Microorganisms (EM4) sebagai bahan organik. Zootec., 32(5): $1-8$. 
Thrall, M.A., G. Weiser, R. Allison, T.W. Campbell. 2012. Veterinary hematology and clinical chemistry. John Wiley \& Sons. New York

Tim Laboratoium Ilmu dan Teknologi Pakan Fakultas Peternakan IPB. 2020. Pengetahuan Bahan Makanan Ternak. Nutri Sejahtera. http://anuragaja.staff.ipb.ac.id/files/2012/ 04/Buku-PBMT.pdf. Diakses pada 30 Juni 2020.

Trapani, L., M. Segatto, V. Pallottini. 2012. Regulation and deregulation of cholesterol homeostasis: the liver as a metabolic Power Station. World J. Hepatology 4(6): 184-190

Trisnadewi, A.A.A.S., I.G.N.G. Bidura, A.T. Umiarti, A.W. Puger. 2015. Pemanfaatan ampas tahu terfermentasi dalam ransum untuk turunkan akumulasi lemak dan kolesterol tubuh itik. Majalah Ilmiah Peternakan, 18(2): 56-60

Wijaya, V. G., Ismoyowati, D.M. Saleh. 2013. Kajian kadar kolesterol dan trigliseridadarah berbagai jenis itik lokal yang pakannya disuplementasi dengan probiotik. J. Ilmiah Peternakan 1(2): 661668.

Yulianti, W., W. Murningsih, V. D. Y. B. Ismadi. 2013. Pengaruh penambahan sari jeruk nipis (Citrus aurantifolia) dalamransum terhadap profil lemak darah itik Magelang jantan. Anim. Agric. J. 2(1): 51-58. 